\title{
Conservation agriculture for improving water productivity in Vertisols of semi-arid tropics
}

\author{
Mukund D. Patil*, Suhas P. Wani and Kaushal K. Garg \\ International Crops Research Institute for the Semi-Arid Tropics, Patancheru 502 324, India
}

Large variability and uncertainty of rainfall are the main limiting factors for crop growth in rainfed agriculture. Agriculture water management interventions are considered as suitable adoption strategy to enhance crop yield, productivity and income in rainfed condition. Three-year experimental data collected at the International Crops Research Institute for the SemiArid Tropics, Patancheru, India are analysed to study the impact of in-situ interventions (tillage and crop residue) on field water balance and grain yield under the two different cropping systems (maize + chickpea sequential and maize/pigeon pea intercropping). One dimensional water balance model is calibrated to capture field hydrology (soil water, surface runoff). Weather data calibrated for 36 years showed that incorporating crop residues reduced surface runoff by $\mathbf{2 8 \%}$ compared to control fields. However, the impact of tillage and residue treatment on soil water was not consistent throughout the growing period. Water productivity values for intercropping systems (WUE $=$ 0.61 to $1.49 \mathrm{~kg} \mathrm{~m}^{-3}$ ) were relatively higher compared to sequential cropping systems (WUE $=0.47$ to $1.06 \mathrm{~kg}$ $\mathrm{m}^{-3}$ ). Second crop in sequential cropping system often suffered from water stress that led to poor crop yield. However, a few rain events at the end of the monsoon period were beneficial to second crop. Simulation results indicated that the conservation agriculture could save up to $30 \%$ yield loss incurred due to water stress during deficit rainfall compared to conventional agricultural practices.

Keywords: Conservation agriculture, crop residue, minimum tillage, rainfed agriculture, semi-arid tropics, soil water balance, Vertisols.

\section{Introduction}

CONSERVATION agriculture (CA) is an important in situ intervention considered for practicing resilient and climatesmart agriculture. The three basic components of CA are: (i) zero or minimum tillage, (ii) retention of crop residues on the soil surface and (iii) crop diversification. Minimal tillage reduces volume and velocity of surface runoff, leading to reduction in soil erosion and nutrient loss; incorporation of crop residues enhances soil water

*For correspondence. (e-mail: m.patil@cgiar.org) availability, reduces evaporation $\operatorname{loss}^{1-3}$, improves infiltration by restricting surface runoff and reduces surface sealing from raindrop impact ${ }^{3}$. Crop diversification reduces the risk of crop failure and is recognized as a cost-effective solution to build resilience into agricultural production system ${ }^{4,5}$. Diversification also brings stability in soil fertility through cultivating legumes with cereals in rotation or intercropping system ${ }^{6,7}$.

Recent studies have reported that CA improved crop productivity by $20-120 \%$ and water productivity by 10 $40 \%$ (refs 8-12). On farm trials showed ${ }^{8}$ that the CA not only improved the crop yield, but also generated higher gross returns compared to farmers' practice. However, other studies reported no improvement or at some cases negative effects on crop yield by adopting such techniques $^{13,14}$. For example, a meta-regression analysis on CA trials in Europe indicated $0-30 \%$ decrease in the crop yield as compared to conventional practices ${ }^{14}$. A general argument is that in addition to $\mathrm{CA}$, appropriate farming practices such as timely planting, balanced nutrient management, crop protection and weed management are necessary to improve crop productivity.

The rainfed agriculture in the semi-arid tropics (SAT) is typically characterized by low crop yields and high risk of crop failure. Frequent dry spells and extreme rain events are the most common characteristics of SAT, which often cause water stress situation and land degradation during rainy season ${ }^{15}$. Important factors influencing soil water dynamics are soil characteristics and climate ${ }^{16,17}$. In India, one fourth of the semi-arid region is covered by Vertisols. These soils have characteristic mineral (smectite) that causes swelling and shrinkage of the soil during wetting and drying events ${ }^{18}$. Infiltration rate when the soil is dry can be as high as $76 \mathrm{~mm} \mathrm{~h}^{-1}$, though the bypass/preferential flow through cracked Vertisols may be much higher. In fact, undisturbed cracks under no-till practices are beneficial to redistribute the water in deeper soil layers ${ }^{19}$. Wider and deeper cracks partially expose sub-surface layers to atmosphere and increases evaporation ${ }^{20,21}$. A significant portion of green water stored in vadose zone may be lost from the system which subsequently could affect the crop water availability and groundwater recharge negatively in the following rainy season.

This article presents results of three-year CA trial conducted at the International Crops Research Institute for the Semi-Arid Tropics (ICRISAT), Patancheru, India. 
The objective of this study was to identify the yield potential of CA trials based on soil water dynamics. CA practices including minimum tillage and incorporation of crop residues were compared with conventional farming practices under two different cropping systems. Observed runoff volume, soil water content and total grain yield were used to simulate the impact of CA practices on in situ water conservation and crop productivity. Modelling and simulation exercise comprise: (i) modification of soil water balance model to incorporate effects of CA practices in Vertisols, (ii) development of production function for grain yield as a function of relative reduction in evapotranspiration and (iii) long-term impact of CA practices on crop yield and runoff using simulated soil water balance and estimated grain yield.

\section{Materials and methods}

\section{Site description}

Field experiments were conducted on experimental watershed at ICRISAT $\left(17.50^{\circ} \mathrm{N} 78.26^{\circ} \mathrm{E}\right.$ and altitude $545 \mathrm{~m})$. Soil at the experimental site is medium black and clayey (Vertisols). Depth-wise distribution of physical and chemical properties of soil is shown in Table 1. The local climate of the study area is semi-arid with average rainfall of $898 \mathrm{~mm}$, of which about $781 \mathrm{~mm}$ rainfall distributed over June to October (kharif season) and about $87 \mathrm{~mm}$ distributed over November to April (rabi season). Maximum and minimum temperature may reach up to $43^{\circ} \mathrm{C}$ and $5^{\circ} \mathrm{C}$ during May and December respectively. Average wind speed during rabi season remains below $2 \mathrm{~m} \mathrm{~s}^{-1}$, which may reach up to $5 \mathrm{~m} \mathrm{~s}^{-1}$ during kharif season.

\section{Field experiments}

Field layout of a micro-watershed for field experiments is shown in Figure 1. The watershed is divided into two parts by a grassed water channel, which carries runoff from both sides. Watershed has gentle slope of less than $1 \%$ (represented by dotted arrows in Figure 1). The field trials were laid out in a split-split plot design with two tillage methods as main treatments: normal tillage and minimum tillage, two sub-treatments of crop residues: no residues retention and retention of all crop residues, and two sub-sub treatments of different cropping system: maize + chickpea sequential and maize/pigeon pea intercropping with four replications. The watershed was divided into four blocks (plot no. 1-8, 9-16, 17-24 and 26-32) with each block containing 8 plots.

\section{Field operations}

Two tillage methods (normal and minimum tillage) were compared under the Broad Bed and Furrow (BBF) land- form. In normal tillage treatment, a sequence of operations such as chisel plough, mould board plough, ridge and blade harrow were carried out before the kharif season. In case of minimum tillage, only ridging operation was done for reshaping BBF. In case of no residues treatments, the entire crop residues are removed from the plot after harvesting, whereas in residues treatment all crop residues $(100 \%)$ were spread on soil surface especially on the beds. In maize + chickpea cropping pattern, maize (cultivar: HTM 5401) was grown during kharif (monsoon) season and chickpea (cultivar: ICCV 2) grown in rabi (post-monsoon) season. In maize/pigeon pea, maize (cultivar: HTM 5401) and a long duration pigeon pea (cultivar: ICPH 2671) were sown together in kharif season. Fertilizer application during kharif season included basal application of di-ammonium phosphate (100 kg ha ${ }^{-1}$ ), gypsum (200 kg ha ${ }^{-1}$ ), Agribor as source of boron $\left(2.5 \mathrm{~kg} \mathrm{ha}^{-1}\right)$ and zinc sulphate $\left(50 \mathrm{~kg} \mathrm{ha}^{-1}\right)$. Two split doses $(66 \%$ and $33 \%)$ of urea with total dose of $150 \mathrm{~kg} \mathrm{~N} \mathrm{ha}^{-1}$ were applied by top dressing at 30 and 60 days after sowing. Micro-nutrients were applied once in two years. First application of micronutrients was done in 2010-11.

\section{Monitoring of soil water and runoff}

Calibrated neutron moisture meter was used to monitor soil water content (SWC) up to $1.2 \mathrm{~m}$ soil depth. First eight plots (shown in Figure 1 by rectangular boxes) were selected for monitoring SWC, which captured combinations of all different treatments. Three access tubes were installed in each treatment plot. Soil water was monitored at the fortnightly interval. Automatic runoff recorders were installed (after 2009) in five treatments plots (as shown by circles in Figure 1) namely, normal tillage with residue, normal tillage without residue, minimum tillage

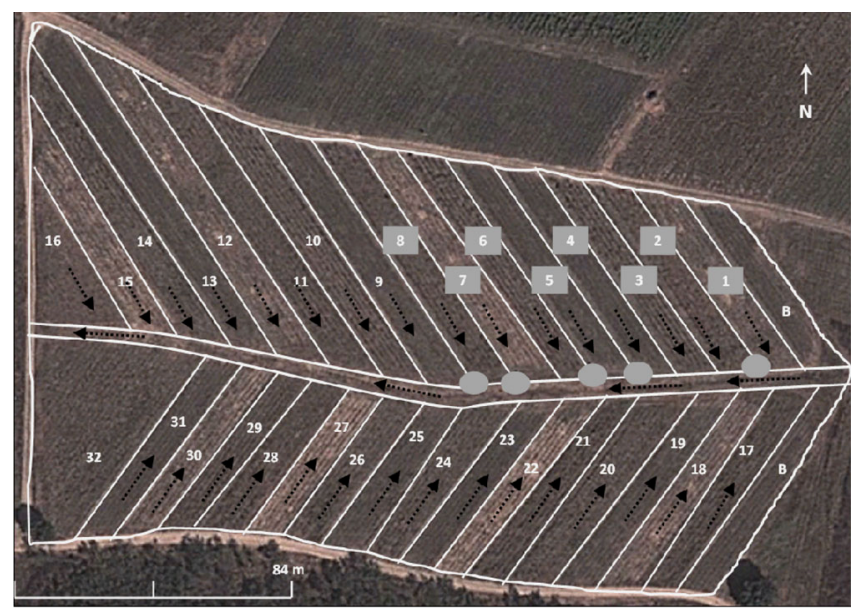

Figure 1. Layout of the experiment. Numbers represent plots. Filled rectangular boxes represent plots with soil water monitoring setups, filled circles represent plots with runoff recorders and black dotted arrows represent direction of runoff flow. 
Table 1. Depth-wise physical and chemical properties of soil at the experimental site

\begin{tabular}{|c|c|c|c|c|c|c|c|}
\hline \multirow[b]{2}{*}{ Depth (m) } & \multirow{2}{*}{\multicolumn{2}{|c|}{ Sand (\%) }} & \multirow{2}{*}{\multicolumn{2}{|c|}{ Silt (\%) }} & \multirow[b]{2}{*}{ Clay (\%) } & \multicolumn{2}{|c|}{ Water content $\left(\mathrm{g} \mathrm{g}^{-1}\right)$ at } \\
\hline & & & & & & $33 \mathrm{kPa}$ & $1500 \mathrm{kPa}$ \\
\hline $0-0.15$ & 27.3 & & 22.9 & & 49.9 & 0.34 & 0.26 \\
\hline $0.15-0.3$ & 25.4 & & 20.9 & & 53.7 & 0.37 & 0.28 \\
\hline $0.3-0.6$ & 23.7 & & 20.5 & & 55.8 & 0.40 & 0.30 \\
\hline $0.6-0.9$ & 21.3 & & 20.4 & & 58.3 & 0.43 & 0.32 \\
\hline $0.9-1.2$ & 21.2 & & 20.0 & & 58.8 & 0.43 & 0.32 \\
\hline $\begin{array}{l}\text { Depth pH } \\
\text { (m) }\end{array}$ & 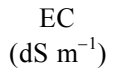 & $\begin{array}{l}\text { Boron } \\
(\mathrm{ppm})\end{array}$ & $\begin{array}{l}\text { Sulphur } \\
\text { (ppm) }\end{array}$ & $\begin{array}{c}\text { Zinc } \\
(\mathrm{ppm})\end{array}$ & $\begin{array}{l}\text { Potassium } \\
\quad(\mathrm{ppm})\end{array}$ & $\begin{array}{l}\text { Phosphorous } \\
\quad(\mathrm{ppm})\end{array}$ & $\begin{array}{c}\text { Organic carbon } \\
(\%)\end{array}$ \\
\hline $0-0.15 \quad 7.9$ & 0.22 & 0.44 & 8.48 & 0.62 & 172 & 4.74 & 0.42 \\
\hline
\end{tabular}

without residues, minimum tillage with residues for maize + chickpea sequence system and minimum tillage with residues for maize/pigeon pea intercropping system.

\section{Modelling field water balance}

Generic soil water balance model was modified to represent CA practices on Vertisols. The field water balance equation is described by mass balance approach

$$
\theta_{t}=\theta_{t-1}+R_{t}+I_{t}-E_{t}-T_{t}-D P_{t}-O_{t},
$$

where $\theta$ is the available water [L], $t$ the time in days [T], $R$ the rainfall [L], $I$ the depth of irrigation [L], DP the deep percolation losses [L], $O$ the runoff losses [L], $E$ the evaporation [L], and $T$ is the transpiration [L]. The weather data are collected from a local weather station at the ICRISAT.

\section{Evapotranspiration}

Values of evapotranspiration were estimated using dual coefficient method described by Allen et al. ${ }^{22}$. This method describes the estimation of crop coefficient $\left(K_{c}\right)$ with respect to wetting pattern of the soil by splitting $K_{\mathrm{c}}$ into two separate coefficients, one for crop transpiration, i.e. the basal crop coefficient $\left(K_{\mathrm{cb}}\right)$ and one for soil evaporation $\left(K_{\mathrm{e}}\right)$.

$$
E T_{\mathrm{c}}=\left(K_{\mathrm{cb}}+K_{\mathrm{e}}\right) E T_{0}
$$

Values for $K_{\mathrm{cb}}$ were estimated following general guide$\operatorname{line}^{23}$. The $K_{\mathrm{cb}}$ values during initial, mid and at end of season were taken as $0.15,1.1$ and 0.3 for maize; 0.15 , 0.9 and 0.3 for chickpea; and $0.15,0.95$ and 0.3 for pigeon pea respectively. In the case of intercropping, combined crop coefficient was estimated by taking weighted average of $K_{\mathrm{cb}}$ of both crops. In the present study, because of length of growing period of both crops is differ- ent, the maximum value between $K_{\mathrm{cb}}$ of both the crops was used for further calculations. The adjusted $K_{\mathrm{cb}}$ values give potential transpiration when the water available for plant uptake is not limited. The actual transpiration $\left(T_{\mathrm{a}}\right)$ can be estimated with respect to SWC depletion in root zone depth.

$$
\begin{aligned}
& T_{\mathrm{a}}=K_{\mathrm{s}} \times K_{\mathrm{cb}} \times E T_{0}, \\
& K_{\mathrm{s}}=\frac{\mathrm{TAW}-D_{\mathrm{r}}}{\mathrm{TAW}-\mathrm{RAW}} \\
& \quad \text { for } D_{\mathrm{r}}>\mathrm{RAW} \text { and } K_{\mathrm{s}}=1 \text { for } D_{\mathrm{r}} \leq \mathrm{RAW}, \\
& \text { TAW }=1000\left(\theta_{0.3}-\theta_{15}\right) Z_{\mathrm{r}}, \\
& \text { RAW }=p \mathrm{TAW},
\end{aligned}
$$

where $K_{\mathrm{s}}$ is the water stress coefficient, TAW the total available water in the root zone [L], RAW the readily available water in root zone [L], $D_{\mathrm{r}}$ the SWC depletion in the root zone [L], $Z_{\mathrm{r}}$ the root zone depth [L], $\theta_{0.3}$ and $\theta_{15}$ are $\mathrm{SWC}$ at 33 and $1500 \mathrm{kPa}$ pressure $\left[\mathrm{L} \mathrm{L} \mathrm{L}^{-1}\right]$, and $p$ is the fraction of TAW that crop can extract from soil without suffering from water stress. A value of $p$ was assumed to be 0.5 .

Values of evaporation coefficient $\left(K_{\mathrm{e}}\right)$ are estimated using the formulae

$$
K_{\mathrm{e}}=K_{\mathrm{r}}\left(K_{\mathrm{c} \max }-K_{\mathrm{cb}}\right) \leq f_{\mathrm{ew}} K_{\mathrm{cmax}}
$$

where $K_{\mathrm{r}}$ is the dimensionless evaporation reduction coefficient dependent on the cumulative depth of water depleted from the top soil and $f_{\text {ew }}$ is the fraction of the wetted soil that was not shaded from vegetation. Evaporation process in cracking soils was divided into three stages $^{22}$. Stage 1, evaporation takes place from wet soil and continues until the soil water depletion is less than readily evaporable water (REW). For stage 1, evaporation value of $K_{\mathrm{r}}$ is equal to 1 . In stage 2 , value of $K_{\mathrm{r}}$ decreases 
as the soil water depletion exceeds REW. Value of $K_{\mathrm{r}}$ can be estimated as

$$
\begin{aligned}
K_{\mathrm{r}}=K_{\mathrm{r} 2}+\left(1-K_{\mathrm{r} 2}\right) & \frac{\mathrm{TEW}_{2}-D_{\mathrm{e}, i-1}}{\mathrm{TEW}_{2}-\mathrm{REW}}, \\
& \text { for } \mathrm{TEW}_{2}>D_{\mathrm{e}, i-1}>\mathrm{REW},
\end{aligned}
$$

where $\mathrm{TEW}_{2}$ is the maximum cumulative depth of evaporation (depletion) from the soil surface layer when $K_{\mathrm{r}}$ is greater than $K_{\mathrm{r} 2}$ (point at which evaporation transitions into stage 3 drying) [L], $K_{\mathrm{r} 2}$ the value for $K_{\mathrm{r}}$ the junction of stage 2 and stage 3 drying, TEW the total evaporable water [L], $D_{\mathrm{e}}$ the SWC depletion due to evaporation and $Z_{\mathrm{e}}$ is the depth of the surface soil layer that is subject to evaporative flux [L]. Value of $K_{\mathrm{r}}$ at the transition point between stage 2 and stage 3 is in the range $0.1-0.4$. In stage $3, K_{\mathrm{r}}$ values further reduce to zero and can be calculated as

$$
\begin{aligned}
K_{\mathrm{r}}=K_{\mathrm{r} 2} \frac{\mathrm{TEW}_{3}-D_{\mathrm{e}, i-1}}{\mathrm{TEW}_{3}-\mathrm{TEW}_{2}} & \\
& \text { for } \mathrm{TEW}_{3}>D_{\mathrm{e}, i-1}>\mathrm{TEW}_{2},
\end{aligned}
$$

where $\mathrm{TEW}_{3}$ is the maximum cumulative depth of evaporation from the soil surface layer when $K_{\mathrm{r}}$ is equal to zero [L]. Allen et al. ${ }^{22}$ used three-stage evaporation approach in cracking heavy clay soil. Values used in their study were $\mathrm{REW}=8 \mathrm{~mm}, \mathrm{TEW}_{2}=50 \mathrm{~mm}, \mathrm{TEW}_{3}=100 \mathrm{~mm}$, and $K_{\mathrm{r} 2}=0.2$. In the current study, values of these parameters were changed to get better fit between observed and simulated SWC and runoff. Further, it was assumed that addition of crop residue reduces evaporation by $20 \%$, but not during rainfall.

\section{Runoff}

The empirical runoff equation was used to estimate surface runoff.

$$
\begin{aligned}
& R=\frac{(P-0.2 \times S)^{2}}{(P+0.8 \times S)}, \\
& S=\frac{(25,400-254 \times \mathrm{CN})}{\mathrm{CN}},
\end{aligned}
$$

where $\mathrm{CN}$ is the curve number of a day under average soil water condition $\left(\mathrm{CN}_{2}\right)$. Value of $\mathrm{CN}_{2}$ depends on land use cover, soil hydrological characteristics, topography and cropping system. Further adjustment in the selected curve number may be done with respect to antecedent water condition. Neitsch et al. ${ }^{24}$ have presented expressions to compute curve number for dry $\left(\mathrm{CN}_{1}\right)$ and wet $\left(\mathrm{CN}_{3}\right)$ situations. In the present computation procedure, the curve number was adjusted with respect to daily water content in terms of relative saturation. The equation for adjusting curve number to dry situation was adapted from Neitsch et $a l^{24}$, whereas for wet situation, instead of a constant, a parameter $\beta$ as a function of $S_{\mathrm{e}}$ was included in the expression as suggested by Neitsch et $a l^{24}$. The following are the expressions used for estimating daily curve number.

$$
\begin{aligned}
& \mathrm{CN}_{1}=\mathrm{CN}_{2} \\
& -\frac{20\left(100-\mathrm{CN}_{2}\right)}{\left(100-\mathrm{CN}_{2}+\exp \left[2.533-0.0636\left(100-\mathrm{CN}_{2}\right)\right]\right)} \\
& \mathrm{CN}_{3}=\mathrm{CN}_{2} \exp \left[\beta\left(100-\mathrm{CN}_{2}\right)\right] \\
& \beta=10^{\left(2.098 S e^{2}-1.818 S e-2.257\right)} \\
& S_{\mathrm{e}}=\frac{\sum_{j=1}^{100} \frac{\theta_{i, j}-\theta_{15_{j}}}{\theta_{s_{j}}-\theta_{15_{j}}}}{100} .
\end{aligned}
$$

where $S_{\mathrm{e}}$ is relative saturation with respect to water content at saturated and permanent wilting point. The purpose of using SWC-based expression for estimating curve number is that the Vertisols swell after wetting which significantly reduces infiltration rate to generate more runoff. On the other hand, when the soils are dry, the cracks in the soil allow rapid infiltration and reduce the runoff.

\section{Soil water dynamics}

A simple and one-dimensional mass balance approach was implemented to simulate soil water dynamics. The model assumes that the given soil profile is a stack of thin soil layers. Upper compartment first gets filled with water whenever there is rainfall or irrigation; and subsequently the lower one fills or partially fills depending on spillover amount. Upper maximum limit for refilling soil is saturated water content $\left(\theta_{\mathrm{S}}\right)$ and lower limit for water depletion is $0.5 \theta_{15}$ in case of evaporation. While during crop water uptake, roots may use water which is available within root zone (greater than $\theta_{15}$ ). Upward movement of water within soil profile has not been considered in the current modelling. Curve numbers were optimized to get better fit between observed and simulated runoff and water content using the observed data of three years. The model was further used for long-term simulation (between 1974 and 2010) under the maize-chickpea cropping system using ICRISAT weather data.

\section{Developing production function}

FAO described the linear relationships between crop yield and water use, where relative yield reduction (ratio 
of actual grain yield and maximum achievable yield) is related to the corresponding relative reduction in evapotranspiration (ratio of total evapotranspiration in a given condition and non-limiting water availability) ${ }^{25}$. In the present study, a linear relationship between relative reduction in evapotranspiration $\left(E_{\mathrm{R}}\right)$ and the total grain yield was used to develop linear production functions. Production function was developed for maize + chickpea cropping system from long-term strategic research data (grain yield data from 1974 to 2010) of ICRISAT research station.

\section{Simulating impact of CA on crop yield}

To parameterize the effects of long-term adaptation of CA practices, it was assumed that water holding capacity of soil will be increased by $20 \%$ (ref. 26), therefore available water capacity of surface $0.6 \mathrm{~m}$ soil layer was increased accordingly, but all other parameters are kept similar to base line (minimum tillage with residue application). Simulations for 36 years (1974-2010) period were carried out to capture wide range of climatic variability. Crop yields were simulated using derived crop production function. On an average, total rainfall received during maize cropping period was $684 \mathrm{~mm}$ (standard deviation $=200 \mathrm{~mm}$ and median $597 \mathrm{~mm}$ ), whereas during chickpea growing period average rainfall was only $22 \mathrm{~mm}$ (standard deviation $=32 \mathrm{~mm}$ and median $13 \mathrm{~mm}$ ). Impact of CA practices was assessed for four rainfall classes: $<25 \%$, $25 \%$ o to median, median to $75 \%$ and $>75 \%$. For maize growing period four rainfall classes were $<498 \mathrm{~mm}, 498-597 \mathrm{~mm}, 597-903 \mathrm{~mm}$ and $>903 \mathrm{~mm}$. In case of chickpea, rainfall classes were $<532 \mathrm{~mm}, 532-650 \mathrm{~mm}, 650-916 \mathrm{~mm}$ and $>916 \mathrm{~mm}$.

\section{Water productivity}

Water productivity (WP) was estimated with respect to total water input that included rainfall received during the growing period and stored soil water. Maize grain equivalent yield $\left(\mathrm{kg} \mathrm{ha}^{-1}\right)$ of both crops in cropping system was used for estimating the WP values. Equivalent grain yield was estimated assuming minimum support prices for maize of Rs 840 per quintal; chickpea, Rs 1760 per quintal and pigeon pea, Rs 2300 per quintal for the year 2009-10. The same prices were used for other two years.

\section{Results and discussion}

Observed runoff and soil water data were used to modify soil water balance model to describe effects of CA practices on Vertisols. Modified model was used to develop relationship between observed grain yield and estimated reduction in evapotranspiration. Finally, long-term impact of CA practices on crop yield and runoff was assessed using the modified soil water balance model and relationship between grain yield and reduction in evapotranspiration.

\section{Soil water balance}

Total rainfall received during maize growing period (June-October) was 780 and $933 \mathrm{~mm}$ in 2009-10 and 2010-11 respectively. Cumulative rainfall and runoff during maize growing period are shown in Figure 2. Observed runoff data during June-August 2010 indicated that out of $565 \mathrm{~mm}$ rainfall, $46.3 \%$ and $44.8 \%$ left the fields as runoff from treatments without residues retention compared to $35.7 \%$ and $33.1 \%$ from treatments with residues retention for normal and minimum tillage respectively, in maize + chickpea system. Similarly, runoff from minimum tillage with residue retention in maize/ pigeon pea system was $37.8 \%$ of the rainfall. High rainfall events during July and August were resulted in sharp increase in cumulative runoff. Figure 2 indicates that crop residue on surface reduced the runoff generation as observed earlier ${ }^{1,2,27,28}$. Runoff from both conventional tillage and minimum tillage was similar. Similarity between runoff for minimum tillage and conventional tillage might be because of the wet Vertisols reducing the infiltration rate and BBF system in both tillage treatments to allow excess water to flow easily ${ }^{27,29}$.

Data on soil water monitored at $0-1.2 \mathrm{~m}$ soil depth are presented for maize + chickpea and maize/pigeon pea plots for 2010-11 (Figure 3). Average amount of soil water stored over the kharif and rabi seasons is shown for different treatment plots. In general, the soil water availability during kharif season was almost similar among the different treatment plots. Frequent rainfall during monsoon compensated the difference occurred due to tillage treatment and residue application on overall soil water. However, soil moisture content in the minimum tillage plots with residue application was maximum among the

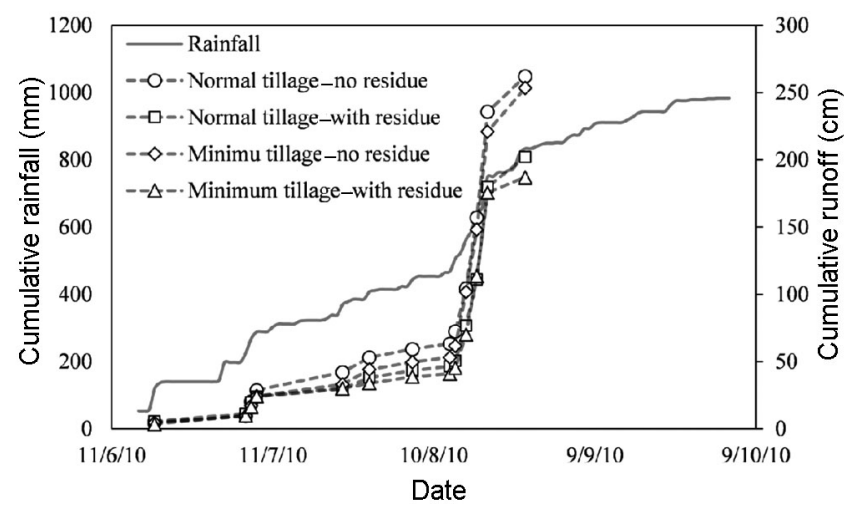

Figure 2. Cumulative rainfall and runoff recorded during kharif season, 2010. 


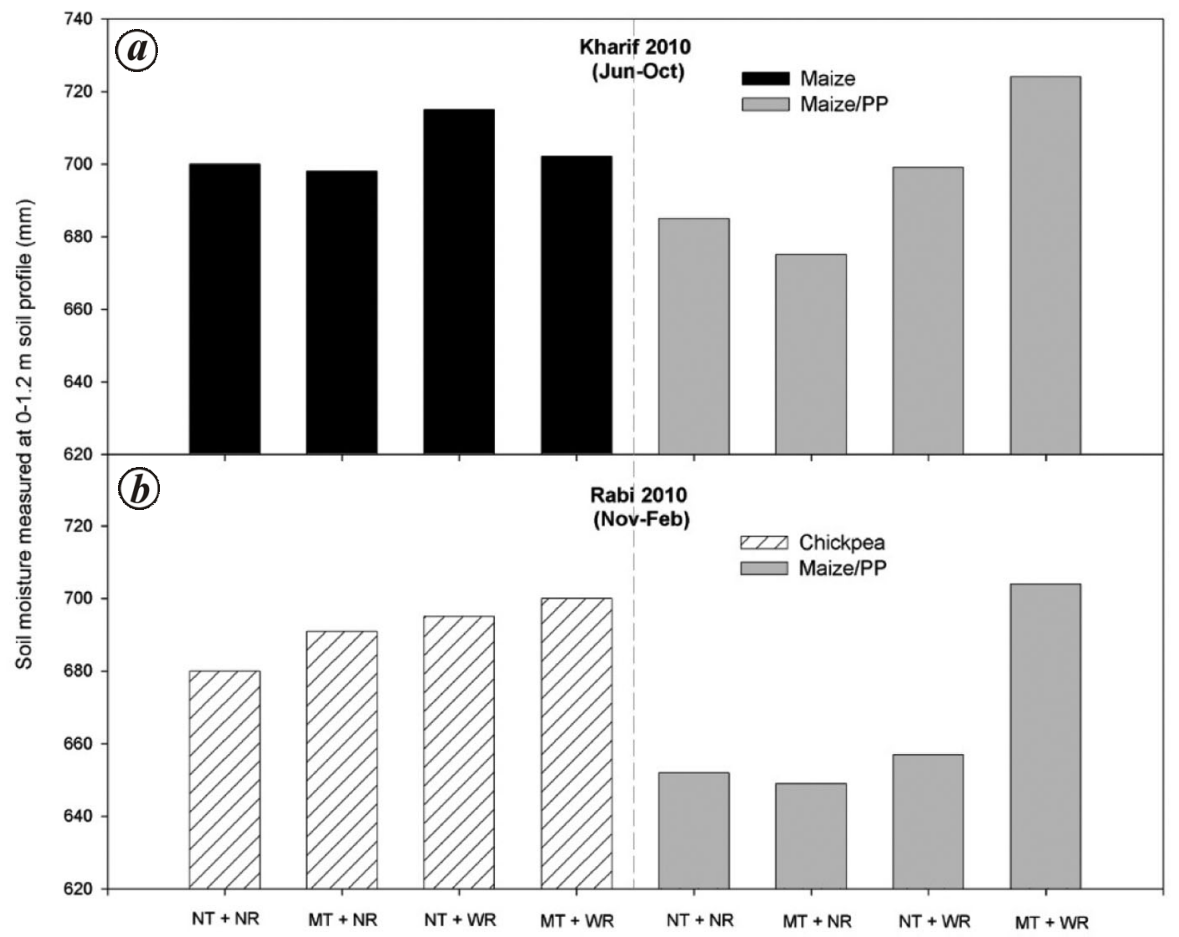

Figure 3. Average soil water measured at $0-1.2 \mathrm{~m}$ soil profile for $(\boldsymbol{a})$ maize and maize/pigeon pea plots during kharif season 2010; (b) chickpea and maize/pigeon pea plots during rabi season 2010. NT, Normal tillage; MT, Minimum tillage; NR, No residue; WR, With residue.

Table 2. Average crop yield (maize, chickpea and pigeon pea) obtained from maize-chickpea and maize/pigeon pea cropping system under various treatments

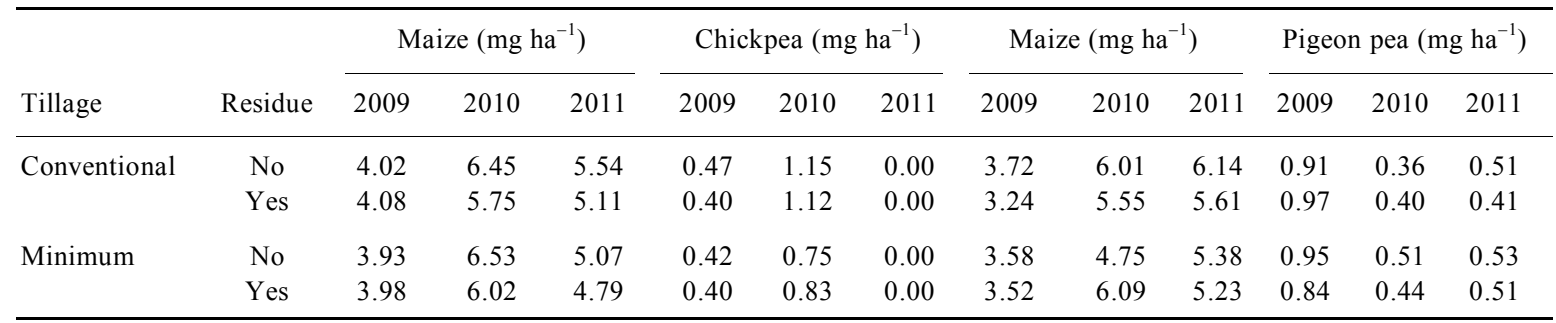

treatments (Figure 3). Application of crop residues was more effective than tillage treatment. Soil water availability in rabi season differed with treatment. Minimum tillage with residue application resulted in more green water than other treatment plots (Figure 3).

In case of maize + chickpea sequential cropping, soil water in conventional tillage plots was higher than the minimum tillage plots during kharif season. Poor distribution of rainfall and the high consumptive water usage by maize crop during late growing period led to formation of a network of deep cracks ${ }^{30}$. These cracks play important role in soil water dynamics in Vertisols ${ }^{31,32}$. Water in dry Vertisols moves through preferential flow to deeper layers and significantly reduces surface runoff. In contrast to the infiltration process, open cracks may enhance evaporative flux as direct evaporation might be possible through deep soil layers ${ }^{20,32}$. Conventional tillage practice disintegrates larger soil clods into finer pieces and fills wider-cracks with loose soil, which may result into early closing of cracks. This may impair the preferential flow and increase the runoff, though it may also reduce the direct evaporation from deeper soil layers. Presence of cracks in untilled soil allows more rainwater to seep into deeper soil layers. In addition to cracks, crop residue provides obstruction to runoff and evaporation and thus conserves water ${ }^{2}$.

\section{Crop yield and water productivity}

Total grain yield for all three crops (maize, chickpea and pigeon pea) in different treatments is shown in Table 2. Irrespective of treatment, average maize yield in maize+ chickpea system was 4.0, 6.2 and $5.1 \mathrm{mg} \mathrm{ha}^{-1}$ in 2009 , 
Table 3. Parameters optimized for capturing tillage and residue effect in Vertisols during model calibration

\begin{tabular}{lccccc}
\hline & \multicolumn{2}{c}{ Normal tillage } & & \multicolumn{2}{c}{ Minimum tillage } \\
\cline { 2 - 3 } \cline { 5 - 6 } & No residue & With residue & & No residue & With residue \\
\hline Curve number & 77 & 69 & & 76 & 68 \\
Soil depth (m) & 1.2 & 1.2 & & 1.2 & 1.2 \\
$Z_{\mathrm{e}}(\mathrm{m})$ & 0.15 & 0.15 & & 0.30 & 0.30 \\
$\mathrm{REW}(\mathrm{m})$ & 0.008 & 0.008 & & 0.016 & 0.016 \\
$\mathrm{TEW}_{2}(\mathrm{~m})$ & 0.05 & 0.05 & & 0.05 & 0.05 \\
$\mathrm{TEW}_{3}(\mathrm{~m})$ & 0.22 & 0.22 & & 0.22 & 0.22 \\
$\mathrm{Kr}_{2}$ & 0.2 & 0.2 & & 0.2 & 0.2 \\
\hline
\end{tabular}

$Z_{\mathrm{e}}$ is depth of soil subjected to evaporation, REW is the depth of readily evaporable water, $\mathrm{TEW}_{2}$ is the maximum cumulative depth of evaporation (depletion) from the soil surface layer when evaporation reduction coefficient $\left(K_{\mathrm{r}}\right)$ is greater than $K_{\mathrm{r} 2}, \mathrm{TEW}_{3}$ is the maximum cumulative depth of evaporation from the soil surface layer when $K_{\mathrm{r}}$ is equal to zero, and $K_{\mathrm{r} 2}$ is the $K_{\mathrm{r}}$ at which evaporation transitions into stage three drying.

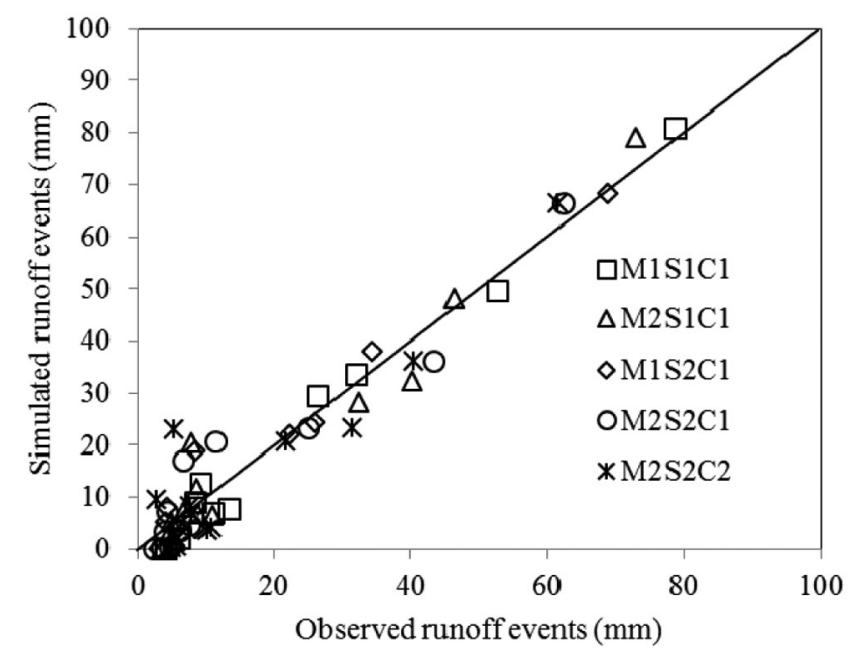

Figure 4. Observed and simulated runoff volumes for the event occurred during 2010 (maize-chickpea cropping system).

2010 and 2011 respectively. On the other hand, average maize yield in maize/pigeon pea system was 3.5, 5.1 and $5.6 \mathrm{mg} \mathrm{ha}^{-1}$ in respective three years. Maize yield in 2010-11 and 2011-12 was 30-40\% higher than that in 2009-10. There are two important reasons for poor maize yield in 2009-10: (i) poor rainfall distribution and water logging and (ii) deficiency of micro-nutrients. Poor rainfall distribution during 2009-10 had led to a water logging situation at the beginning of the crop growth stage. Moreover results of soil analysis showed that the soil at experimental site was deficient in zinc, sulphur and boron, which is important yield-limiting factor ${ }^{33}$. Micronutrients (zinc, boron and sulphur application) along with major nutrients were also applied in the year 2010-11.

Comparison of maize yield between maize + chickpea sequential system and maize/pigeon pea intercropping showed that maize yield in the case of maize + chickpea sequential system was $10 \%$ higher than the maize/pigeon pea intercropping system during 2009-10 and 2010-11. Interestingly, maize yield obtained from maize/pigeon pea intercropping was higher than the sole maize (maize + chickpea system) in the year 2011. Increase in maize yield with pigeon pea intercropping is attributed to replenishment of $\mathrm{N}$ in soil through biological $\mathrm{N}$ fixation and $\mathrm{N}$ release from incorporated residue of pigeon pea ${ }^{7}$. Irrespective of the treatment, chickpea yield during rabi season in maize + chickpea system was on an average 0.42 and $0.96 \mathrm{mg} \mathrm{ha}^{-1}$ in 2009-10 and 2010-11 respectively. Despite normal rainfall during 2009-10, chickpea in rabi experienced water scarcity which resulted in relatively lesser yield (nearly half) than 2010-11. Whereas total rainfall received during 2011-12 was only $525 \mathrm{~mm}$ which resulted in entire crop failure of chickpea. On the other hand, early established deep rooting system in pigeon pea used in situ soil water from deep soil layers during post-rainy season. Thus although chickpea crop entirely failed during 2011-12, pigeon pea yield was nearly $0.49 \mathrm{mg} \mathrm{ha}^{-1}$. Pigeon pea yield was also linked to rainfall distribution. Higher yields were observed during 2009 when the rainfall was near to normal as compared to low yield when the rainfall was $40 \%$ deficit in 2011 . Poor yield in 2010 was due to insect attack on pigeon pea.

Crop yield obtained from different treatments (tillage and residue) was not significant. One of the reasons could be that soils at experimental site were deep and crop water requirements at most of the time were fulfilled both in conventional and conservation systems except in 2011-12, as the rainfall received at experimental site was normal and above normal.

Water productivity values for maize + chickpea cropping system were $0.48,0.70$ and $0.98 \mathrm{~kg} \mathrm{~m}^{-3}$ as compared to $0.55,0.64$ and $1.4 \mathrm{~kg} \mathrm{~m}^{-3}$ for maize/pigeon pea system during 2009, 2010 and 2011 respectively. Higher water productivity for maize/pigeon pea system in 2009 was because of high value of pigeon pea compared to chickpea, whereas less water productivity in 2010 was because 


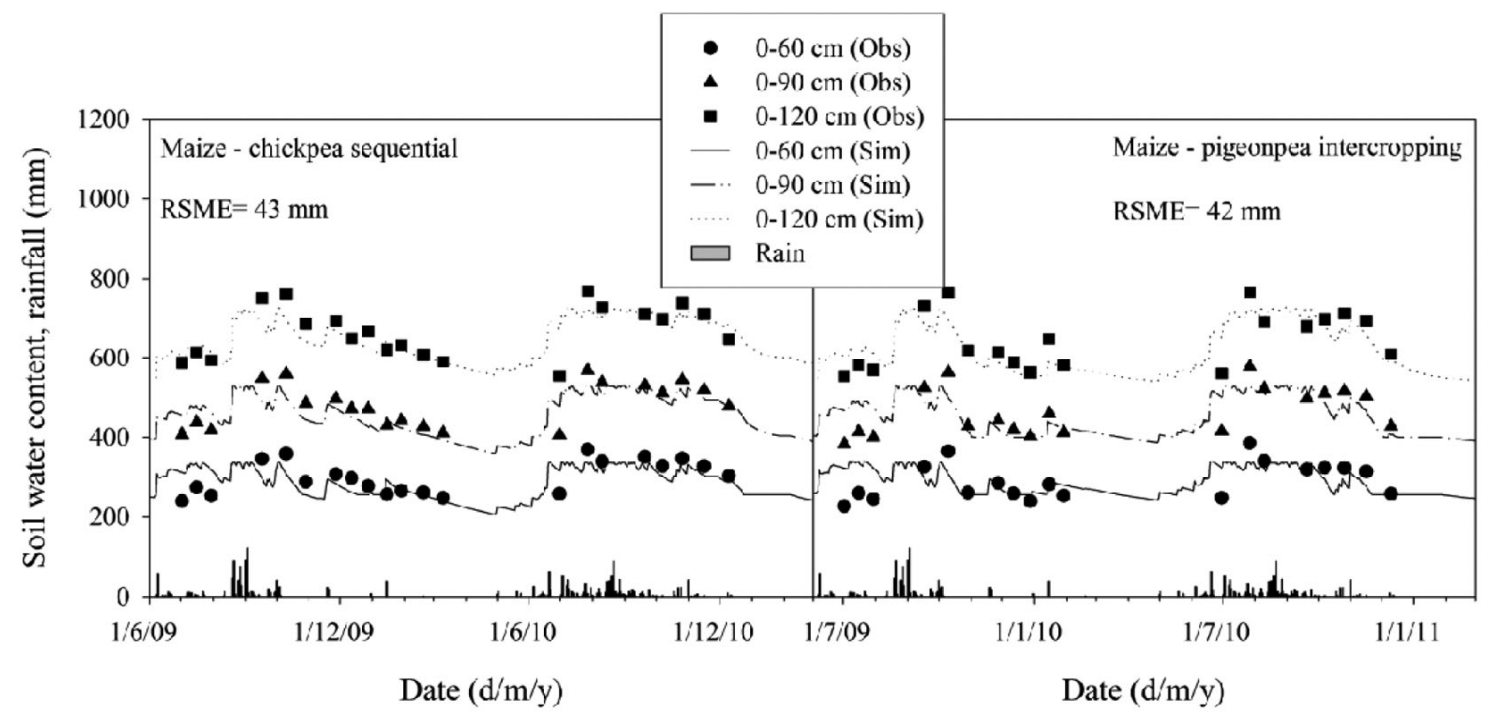

Figure 5. Observed and simulated water content in soil profile for conventional tillage and without residue and maizechickpea cropping pattern and maize-pigeon pea intercropping.

of low pigeon pea yields. In 2011, despite the low rainfall, high water productivity values indicated the grain produced per unit rainfall was greater than previous two years. The success of maize/pigeon pea intercropping system also indicated possible adaptation strategy for climate smart agriculture ${ }^{4}$.

\section{Calibration of soil water balance model}

Table 3 shows the parameters optimized for capturing tillage and residue effect on field scale hydrology. Figure 4 shows simulated and observed runoff event during maize growth period in 2010. Observed surface runoff is well captured with simulated values for different tillage and residue treatments. Modified curve numbers for no residues and with residues retention treatment were 77 and 69 respectively, for normal tillage. In case of minimum tillage, curve number reduced by one compared to normal tillage. Root mean square error (RMSE) and coefficient of determination $\left(R^{2}\right)$ between observed and simulated runoff was $5.2 \mathrm{~mm}$ and 0.94 respectively. Similarly, Figure 5 shows observed and simulated soil water from June 2009 to March 2011 for selected treatment (conventional tillage and without crop residue) under maize + chickpea and maize/pigeon pea cropping system. The modified soil and water balance model captured soil water dynamic reasonably well. Depth of soil available for evaporation for normal tillage was assumed to be $0.15 \mathrm{~m}$ compared to $0.30 \mathrm{~m}$ for minimum tillage soil. The basis of this assumption is that soil with minimum tillage treatment showed cracks on the soil surface. RMSE in estimating soil water was $43 \mathrm{~mm}$ and $42 \mathrm{~mm}$ under maize + chickpea and maize/pigeon pea cropping system respectively.

\section{Relationship between relative evapotranspiration reduction and grain yield}

Calibrated soil water balance model used to simulate maize + chickpea cropping system for twelve years between 1974 and 2010. Production functions for maize and chickpea yield were developed using simulated relative reduction in evapotranspiration and observed grain yields. Relative reduction in evapotranspiration during kharif season varies between $0 \%$ and $19 \%$, whereas during the chickpea growing season it is between $27 \%$ and $78 \%$. Figure 6 shows the relationship obtained for production functions of maize and chickpea. Data points $(n=12)$ in these figures represent grain yield of maize (Figure $6 a$ ) and chickpea (Figure $6 b$ ). The conditions assumed in these simulations are representative to normal tillage without residue retention. Linear equation obtained for maize and chickpea yield as a function of relative reduction in evapotranspiration was used to assess impact of conservation agricultural practices on grain yield.

\section{Long-term impact of CA on surface runoff and crop yield}

Figure 7 shows the effects of conventional and CA on simulated runoff in different rainfall years. Results showed that CA had large impact on reducing surface runoff compared to conventional practice. Runoff reduction in dry years was higher compared to wet years. On an average, conservation practice reduced surface runoff by $30 \%$ compared to the conventional practices. This amount enhances soil water availability for plant uptake and also contributes in deep percolation. Figure 8 shows simulated average maize (Figure $8 a$ ) and chickpea (Figure $8 b$ ) 


\section{(a)}

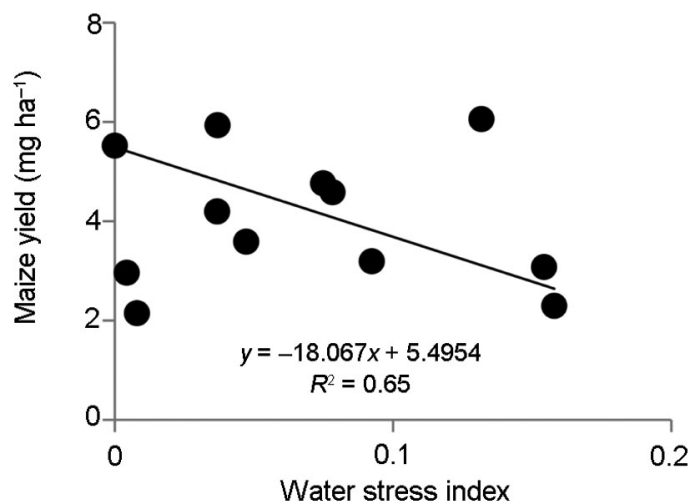

(b)

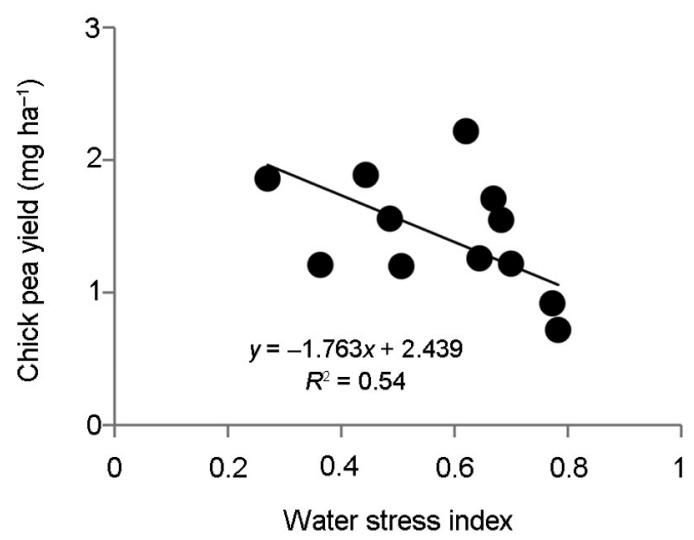

Figure 6. Relationship between observed grain yield and simulated water stress index for (a) maize; (b) chickpea.

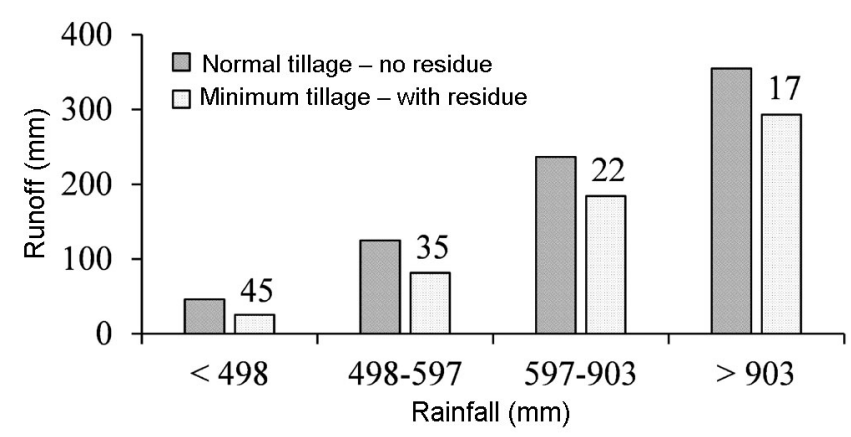

Figure 7. Effects of tillage and residue treatments on simulated runoff during maize growing period for 36 years (1974-2011). Four rainfall classes represent the quantity less than first quartile, between first and second quartile, between second and third quartile, greater than third quartile.

yield relative to rainfall classes. Simulation results showed that CA enhanced maize yield by $46 \%$ in low rainfall years compared to conventional system. Yield increase during high rainfall years ranged between $2 \%$ and $15 \%$. In case of chickpea, additional in situ soil water resulted into $13-18 \%$ more crop yield compared to the conventional practice.

Simulations showed that conservation practice has potential to build system resilience for alleviating water scarcity in rained areas and reduce risk of crop failure. There was no significant difference in crop yields (a)

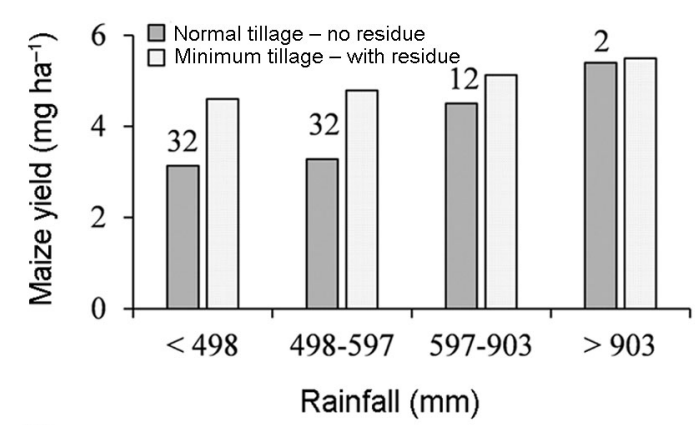

(b)

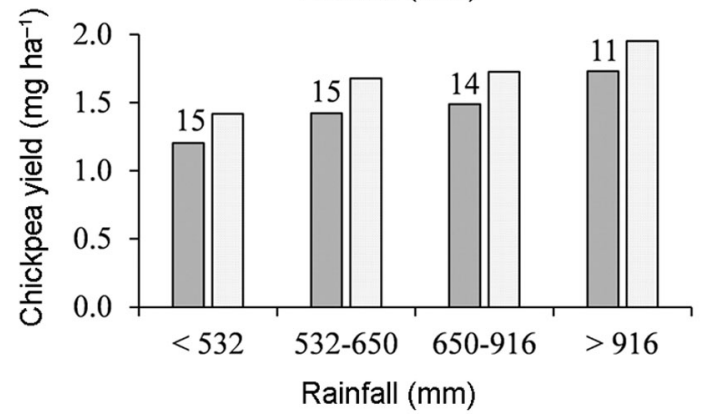

Figure 8. Effects of tillage and residue treatments on estimated yield of maize $(\boldsymbol{a})$ and chickpea (b) for 36 years (1974-2011). Four rainfall classes represent the quantity less than first quartile, between first and second quartile, between second and third quartile, greater than third quartile.

between conventional and conservation system during normal and wet years, but it helped in enhancing ecosystem services such as deep percolation and groundwater recharge. Moreover, reduced surface runoff helped in reducing water logging and flooding situation at downstream location and reducing soil erosion.

\section{Conclusions}

Effects of conservation agriculture practices on crop yield and field scale hydrology were analysed and modelled using three-year field experimental data. Water productivity values were estimated based on maize equivalent grain yield, total rainfall received and simulated soil water content. Maize/pigeon pea intercropping system is more sustainable and associated with less risk compared to maize + chickpea sequential cropping system. In terms of soil and water conservation, surface runoff observed in conservation practices was $28 \%$ less compared to the conventional system, which may be attributed to residues retention than minimum tillage. The long-term simulation results showed that $\mathrm{CA}$ helps in reducing water stress in dry years and reduces the risk of crop failure.

1. Araya, T. et al., Effects of conservation agriculture on runoff, soil loss and crop yield under rainfed conditions in Tigray, northern Ethiopia. Soil Use Manage., 2011, 27, 404-414.

2. Araya, T. et al., Medium-term effects of conservation agriculture based cropping systems for sustainable soil and water management 


\section{SPECIAL SECTION: SOIL AND WATER MANAGEMENT}

and crop productivity in the Ethiopian highlands. Field Crops Res., 2012, 132, 53-62.

3. Potter, K. N., Torbert, H. A. and Morrison, J. E. J., Tillage and residue effects on infiltration and sediment losses on Vertisols. Am. Soc. Agric. Eng., 1995, 38, 1413-1419.

4. Rusinamhodzi, L., Corbeels, M., Nyamangara, J. and Giller, K. E., Maize-grain legume intercropping is an attractive option for ecological intensification that reduces climatic risk for smallholder farmers in central Mozambique. Field Crops Res., 2012, 136, 12 22.

5. Lin, B. B., Resilience in agriculture through crop diversification: Adaptive management for environmental change. Bioscience, 2011, 61, 183-193

6. Myaka, F. et al., Yields and accumulations of $\mathrm{N}$ and $\mathrm{P}$ in farmermanaged intercrops of maize-pigeonpea in semi-arid Africa. Plant Soil, 2006, 285, 207-220.

7. Aslam, M., Mahmood, I. A., Peoples, M. B., Schwenke, G. D. and Herridge, D. F., Contribution of chickpea nitrogen fixation to increased wheat production and soil organic fertility in rain-fed cropping. Biol. Fertic. Soils, 2003, 38, 59-64.

8. Ngwira, A. R., Aune, J. B. and Mkwinda, S., On-farm evaluation of yield and economic benefit of short term maize legume intercropping systems under conservation agriculture in Malawi. Field Crops Res., 2012, 132, 149-157.

9. Rockstrom, J. et al., Conservation farming strategies in east and southern Africa: yields and rain water productivity from on-farm action research. Soil Till. Res., 2009, 103, 23-32.

10. Ito, M., Matsumoto, T. and Quinones, M. A., Conservation tillage practice in sub-Saharan Africa: The experience of Sasakawa Global 2000. Crop Protect., 2007, 26, 417-423.

11. Li, H. W., Gao, H. W., Wu, H. D., Li, W. Y., Wang, X. Y. and He, J., Effects of 15 years of conservation tillage on soil structure and productivity of wheat cultivation in northern China. Austr. J. Soil Res., 2007, 45, 344-350.

12. Wang, X. B., Cai, D. X., Hoogmoed, W. B., Oenema, O. and Perdok, U. D., Developments in conservation tillage in rainfed regions of north china. Soil Till. Res., 2007, 93, 239-250.

13. Baudron, F. D. R., Tittonell, P., Corbeels, M., Letourmy, P. and Giller, K. E., Comparative performance of conservation agriculture and current smallholder farming practices in semi-arid Zimbabwe. Field Crops Res., 2012, 132, 117-128.

14. Van den Putte, A., Govers, G., Diels, J., Gillijns, K. and Demuzere, M., Assessing the effect of soil tillage on crop growth: a meta-regression analysis on European crop yields under conservation agriculture. Euro. J. Agron., 2010, 33, 231-241.

15. Barron, J., Rockstrom, J., Gichuki, F. and Hatibu, N., Dry spell analysis and maize yields for two semi-arid locations in east Africa. Agric. Forest Meteor., 2003, 117, 23-37.

16. Barron, J., Rockstrom, J., Gichuki, F. and Hatibu, N., Dry spell analysis and maize yields for two semi-arid locations in east Africa. Agric. Forest Meteor., 2003, 117, 23-37.

17. Pathak, P., Sudi, R., Wani, S. P. and Sahrawat, K. L., Hydrological behavior of Alfisols and Vertisols in the semi-arid zone: Implications for soil and water management. Agric. Water Manage., 2013, 118, 12-21.

18. Greeneke, R., Shrinkage of clay soils - statistical correlation with other soil properties. Geoderma, 1974, 11, 243-257.

19. Loch, R. J. and Coughlan, K. J., Effects of zero tillage and stubble retention on some properties of a cracking clay. Aust. J. Soil Res., 1984, 22, 91-98.
20. Ritchie, J. T. and Adams, J. E., Field measurement of evaporation from soil shrinkage cracks. Soil Sci. Soc. Am. J., 1974, 38, 131134.

21. Selim, H. M. and Kirkham, D., Soil temperature and water content changes during drying as influenced by cracks - a laboratory experiment. Soil Sci. Soc. Am. Proc., 1970, 34, 565-569.

22. Allen, R. G., Pereira, L. S., Smith, M., Raes, D. and Wright, J. L., FAO-56 dual crop coefficient method for estimating evaporation from soil and application extensions. J. Irri. Drain. Eng., 2005, 131, 2-13.

23. Allen, R. G., Pereira, L. S., Raes, D. and Smith, M., Crop evapotranspiration-guidelines for computing crop water requirements-FAO irrigation and drainage paper 56, Food and Agriculture Organization of the United Nations, Rome, 1998.

24. Neitsch, S. L., Arnold, J. G., Kiniry, J. R. and Williams, J. R., Soil and water assessment tool theoretical documentation, version 2009. In Texas Water Resources Institute Technical Report No 406, Texas A\&M University System, Temple, TX.

25. Steduto, P., Hsiao, T. C., Raes, D. and Fereres, E., AquaCrop - the FAO crop model to simulate yield response to water: I. Concepts and underlying principles. Agron. J., 2009, 101, 426-437.

26. Sahrawat, K. L., Wani, S. P., Pathak, P. and Rego, T. J., Managing natural resources of watersheds in the semi-arid tropics for improved soil and water quality: a review. Agric. Water Manage., 2010, 97, 375-381.

27. Oicha, T. et al., Short-term effects of conservation agriculture on Vertisols under tef (Eragrostis tef (zucc.) trotter) in the northern Ethiopian highlands. Soil Till. Res., 2010, 106, 294-302.

28. Engel, F. L., Bertol, I., Ritter, S. R., Paz Gonzalez, A., PazFerreiro, J. and Vidal Vazquez, E., Soil erosion under simulated rainfall in relation to phenological stages of soybeans and tillage methods in Lages, SC, Brazil. Soil Till. Res., 2009, 103, $216-$ 221.

29. Erkossa, T., Stahr, K. and Gaiser, T., Effect of different methods of land preparation on runoff, soil and nutrient losses from a Vertisol in the Ethiopian highlands. Soil Use Manage., 2005, 21, 253-259.

30. Favre, F., Boivin, P. and Wopereis, M. C. S., Water movement and soil swelling in a dry, cracked Vertisol. Geoderma, 1997, 78, $113-123$.

31. Kulasekera, P. B., Parkin, G. W. and von Bertoldi, P., Using soil water content sensors to characterize tillage effects on preferential flow. Vadose Zone J., 2011, 10, 683-696.

32. Elias, E. A., Salih, A. A. and Alaily, F., Cracking patterns in the Vertisols of the Sudan Gezira at the end of dry season. Int. Agrophys., 2001, 15, 151-155.

33. Chander, G., Wani, S. P., Sahrawat, K. L. and Jangwad, L. S., Balanced plant nutrition enhances rainfed crop yields and water productivity in Jharkhand and Madhya Pradesh states of India. J. Tropic Agric., 2012, 50, 24-29.

ACKNOWLEDGEMENTS. Field experiments were conducted by a multi-disciplinary team. We acknowledge the help of Drs Ram Jat and Girish Chander and Mr Pardhasaradhi during these experiments.

doi: $10.18520 / \mathrm{cs} / \mathrm{v} 110 / \mathrm{i} 9 / 1730-1739$ 